\title{
Sikap dan Perilaku Konsumen Minyak Goreng Curah dan Kemasan di Kota Pekanbaru
}

\author{
Yeni Kusumawaty ${ }^{1}$, Susy Edwina, ${ }^{2}$ Nurny Sofwah Sifqiani ${ }^{3}$ \\ Universitas Riau \\ 1yeni.kusumawaty@lecturer.unri.ac.id \\ ${ }^{2}$ susy.edwina@lecturer.unri.ac.id \\ ${ }^{3}$ nurny.sofwahsifqiani@student.unri.ac.id
}

\begin{abstract}
ABSTRAK
Penelitian ini bertujuan untuk menganalisis sikap dan perilaku belanja konsumen untuk produk minyak goreng curah dan kemasan. Penelitian dilakukan di Kota Pekanbaru, dengan pertimbangan merupakan ibu kota Provinsi Riau serta adanya perbaikan tingkat ekonomi dan perkembangan ritel modern dan tradisional yang lebih lengkap. Populasi pada penelitian ini adalah seluruh konsumen minyak goreng yang ada di Kota Pekanbaru. Penelitian ini menggunakan metode survey dengan jumlah sampel 100 orang. Data dianalisis menggunakan model sikap, model norma subjektif dan Theory of Reasoned Action (TRA). Hasil penelitian menunjukan sikap konsumen positif terhadap minyak goreng curah dan kemasan. Secara keseluruhan sikap konsumen cukup baik terhadap atribut minyak goreng curah dan sikap baik terhadap atribut minyak goreng kemasan. Atribut utama yang menentukan sikap konsumen terhadap minyak goreng curah adalah harga yang murah, sedangkan pada minyak goreng kemasan adalah higienis. Perilaku konsumen terhadap pembelian minyak goreng curah dan kemasan adalah $1.248,76$ dan $2.060,77$, artinya perilaku konsumen terhadap minyak goreng kemasan lebih baik dibandingkan minyak goreng curah.
\end{abstract}

Kata Kunci : Minyak Goreng, Konsumen, Sikap, Perilaku

\begin{abstract}
This study aimed to analyze consumer attitude and behavior towards unbranded and branded cooking oil. This research was conducted in Pekanbaru City with the consideration that this is the capital city of Riau Province which shows economic improvement and development of a more complete choices of modern and traditional retailers. The population in this study was all consumers of cooking oil in Pekanbaru City. This study applied survey method with total respondents of 100. Data was analyzed by attitude model, subjective norm model and Theory of Reasoned Action (TRA). The results showed positive consumer attitudes towards unbranded and branded cooking oil. Overall consumers' attitude towards unbranded cooking oil attributes is good enough while the attitude towards the attributes of branded cooking oil is good. The main attribute that determines consumer attitudes towards unbranded cooking oil is low price, while for branded cooking oil is hygiene. Consumer behavior towards the purchase of unbranded and branded cooking oil is 1,248.76 and 2,060.77, which means consumer behavior towards branded cooking oil is better than unbranded cooking oil
\end{abstract}

Keywords: Cooking Oil, Consumer, Attitude, Behavior

Naskah diterima: 7 April 2019, direvisi: 28 Juni 2019, diterbitkan: 16 September 2019

ISSN: 2355-0295, e-ISSN: 2549-8932

http://ejournal.bsi.ac.id/ejurnal/index.php/ecodemica 


\section{PENDAHULUAN}

Kota Pekanbaru merupakan ibukota Provinsi Riau, dengan kecenderungan penduduk yang beragam dalam memilih produk termasuk bahan pokok. Tahun 2014, Pekanbaru adalah kota keempat berpenduduk terbanyak di Sumatera, setelah Medan, Palembang dan Bandar Lampung. Perekonomian di Kota Pekanbaru berkembang dan menjadi kota metropolitan dengan banyaknya ritel yang menyediakan minyak goreng kelapa sawit dengan beragam pilihan dalam bentuk kemasan dan curah.

Minyak goreng adalah salah satu produk turunan minyak nabati dan sangat dibutuhkan dalam kehidupan sehari-hari. Produk ini merupakan salah satu dari sembilan bahan pokok yang dikonsumsi hampir seluruh masyarakat Indonesia, karena termasuk komoditas strategis. Kelangkaan minyak goreng dapat menimbulkan dampak ekonomis dan politis terhadap perekonomian nasional (Qorima dkk, 2014).

Selain itu pengolahan makanan yang banyak dilakukan masyarakat adalah menggoreng yang tentunya membutuhkan minyak goreng. Weldi (2010) menjelaskan bahwa penggunaan minyak goreng sebagai pengolahan suatu makanan demikian luas. Makanan yang digoreng cenderung lebih disukai dibanding direbus, karena lebih gurih dan renyah (Aminah, 2010).

Haryanti dkk (2014) menyatakan bahwa minyak goreng yang beredar di masyarakat terdiri dari dua kategori yaitu minyak goreng curah dan kemasan. Minyak goreng curah adalah minyak goreng yang tidak memiliki merek dan biasanya dijual dalam satuan massa (kilogram). Sedangkan minyak goreng kemasan adalah minyak goreng yang memiliki merek yang biasanya dikemas dalam bentuk botol plastik, refill, dan jerigen. Minyak goreng kemasan umumnya memiliki warna yang bening dan tidak membeku pada suhu kamar, sedangkan minyak goreng curah umumnya memiliki warna kuning bercampur putih dan terkadang membeku di suhu kamar. Peralihan pola konsumsi masyarakat dari minyak goreng curah ke minyak goreng bermerek pun semakin besar. Minyak goreng yang dikemas dalam botol atau plastik dianggap lebih bersih dan higienis oleh masyarakat daripada minyak goreng yang dijual eceran oleh pedagang keliling atau pasar tradisional yang ditempatkan di dalam jerigen dan drum. Hal ini membuka lebar peluang pasar bagi industri minyak goreng bermerek (Bukhori dan Tutik, 2017).

Minyak goreng yang akan dikonsumsi selayaknya tidak membahayakan manusia serta dilengkapi dengan label yang sesuai dengan ketentuan, sehingga pemerintah mengeluarkan kebijakan tentang minyak goreng wajib kemasan. Kebijakan pemerintah ini dimulai dari Peraturan Menteri Perdagangan Republik Indonesia Nomor 80/M-DAG/PER/10/2014. Peraturan ini mengalami dua kali perubahan yaitu pada Peraturan Menteri Perdagangan Republik Indonesia Nomor 21/M-DAG/PER/3/2015 dan Nomor 09/M-DAG/PER/2/2016. Selain itu untuk mendukung kebijakan ini pemerintah mengeluarkan minyak goreng merek Minyakita yang merupakan program bersama antara pemerintah dan produsen minyak goreng yang diharapkan lebih higienis dengan harga yang lebih stabil. Minyakita dikemas dalam kemasan plastik sederhana berbentuk bantal ukuran 1 liter (Departemen Perdagangan Republik Indonesia, 2009). Namun, minyak goreng Minyakita tidak lama beredar karena sudah tidak terlihat beredar di Kota Pekanbaru sejak Bulan September 2018. Masyarakat Kota Pekanbaru yang terdiri dari berbagai tingkat ekonomi membuat perubahan sikap, norma subjektif dan perilaku konsumen dalam membeli menjadi lebih selektif. Mutu dan harga suatu produk menjadi pertimbangan konsumen dalam membeli produk. Selain itu pendapatan rumah tangga konsumen yang beragam serta kebutuhan yang harus dipenuhi oleh setiap rumah tangga, mempengaruhi perilaku konsumen dalam membeli minyak goreng. Adanya kebijakan pemerintah tentang minyak goreng wajib kemasan pada tahun 2014 serta dikeluarkannya minyak goreng kemasan sederhana dengan merek Minyakita oleh pemerintah, dapat mempengaruhi konsumen dalam pembelian minyak goreng. Tujuan dari penelitian ini adalah untuk menganalisis sikap dan perilaku konsumen produk minyak goreng curah dan kemasan di Kota Pekanbaru. 


\section{KAJIAN LITERATUR Minyak Goreng}

Menurut Standar Nasional Indonesia (SNI 3741), minyak goreng adalah bahan pangan dengan komposisi utama trigliserida yang berasal dari bahan nabati dengan atau tanpa perubahan kimiawi termasuk hidrogenasi, pendinginan dan telah melalui proses rafinasi atau pemurnian yang digunakan untuk menggoreng (Badan Standardisasi Nasional, 2013). Minyak goreng dikategorikan sebagai komoditas yang bersifat multiguna untuk pangan dikonsumsi langsung ataupun menjadi bahan baku bagi banyak industri. Minyak goreng yang dikonsumsi masyarakat adalah minyak yang berasal dari lemak tumbuhan atau hewan yang dimurnikan dan berbentuk cair dalam suhu kamar dan biasanya digunakan untuk menggoreng bahan makanan (Fitriana, 2015). Terdapat berbagai macam tanaman sebagai sumber pembuatan minyak goreng dan salah satunya dari tanaman kelapa sawit.

Menurut Lempang dkk (2016), terdapat dua jenis minyak goreng yaitu, minyak goreng curah dan minyak goreng kemasan. Perbedaan minyak goreng curah dan minyak goreng kemasan terletak pada penyaringannya yang berpengaruh terhadap kualitas minyak goreng. Minyak goreng kemasan mengalami dua kali penyaringan sedangkan minyak goreng curah mengalami satu kali penyaringan

\section{Minyak Goreng Curah}

Minyak goreng curah merupakan minyak goreng yang dijual ke pasar tanpa menggunakan merek dan label diukur dalam satuan massa (kilogram). Minyak goreng curah dijual ke pasar tanpa menggunakan merek dan label produk yang biasanya ditempatkan di dalam jerigen besar atau drum lalu dijual kepada konsumen secara eceran (Bukhori dan Tutik, 2017).

Menurut Fitriana (2015), minyak goreng jenis curah diproduksi dari minyak kelapa sawit yang proses penyaringannya hanya $1 \mathrm{x}$ sehingga dari warnanya berbeda dengan minyak goreng bermerek yang lebih jernih. Minyak goreng kualitas rendah (curah) biasanya berasal dari bahan baku (CPO) yang bermutu rendah, untuk diproduksi menjadi minyak goreng yang berkualitas tinggi akan membutuhkan biaya produksi yang mahal, sehingga minyak ini diproduksi menjadi minyak goreng curah.

Minyak goreng curah mengandung lemak jenuh lebih banyak sehingga kurang sehat. Selain itu, pendistribusian minyak goreng curah dari pabrik ke eceran melalui rantai distribusi yang panjang, sehingga dikhawatirkan aspek higienitas minyak curah kurang layak untuk konsumen.

\section{Minyak Goreng Kemasan}

Minyak goreng kemasan adalah minyak goreng yang diukur dalam satuan volume (liter) dan dikemas dengan botol, plastik refill, dan jerigen. Minyak goreng kemasan bermerek ditawarkan ke pasar dengan menggunakan kemasan, merek, dan label produk (Bukhori dan Tutik, 2017). Minyak goreng kemasan biasanya mempunyai mutu yang lebih tinggi dibandingkan dengan minyak goreng curah. Minyak goreng kemasan ini biasanya menggunakan teknologi proses yang lebih tinggi. Kelebihan proses produksi tersebut misalnya dilakukan dua kali penyaringan, dilakukan proses deodorisasi dan pemucatan, sehingga dihasilkan minyak goreng yang lebih jernih dan tidak berbau (Fitriana, 2015). Sedangkan berdasarkan aspek kebersihan serta kualitas produk, minyak goreng kemasan memiliki keunggulan yang lebih dibandingkan dengan minyak goreng curah sehingga aman untuk dikonsumsi.

\section{Perilaku Konsumen}

Perilaku konsumen menurut Hawkins dan Mothersbaugh (dalam Tjiptono dan Diana, 2016) adalah studi mengenai individu, kelompok atau organisasi dan proses-proses yang mereka gunakan adalah untuk menyeleksi, mendapatkan, menggunakan, dan menghentikan pemakaian produk, jasa, pengalaman, atau ide untuk memuaskan kebutuhan, serta dampaknya terhadap konsumen. Perilaku konsumen adalah studi tentang bagaimana individu, kelompok, dan organisasi memilih, membeli, menggunakan, dan bagaimana barang, jasa, ide, atau pengalaman untuk memuaskan kebutuhan dan keinginan mereka (Kotler dan Keller, 2010).

Menurut McKechnie (dalam Sangadji dan Sopiah, 2013) tahap-tahap perilaku konsumen yang meliputi (1) tahap untuk merasakan adanya kebutuhan dan keinginan; (2) usaha untuk mendapatkan produk, mencari 
informasi tentang produk, mencari informasi tentang produk, harga, dan saluran distribusi; (3) pengonsumsian, penggunaan, dan pengevaluasian produk setelah digunakan; dan (4) tindakan pascapembelian yang berupa perasaan puas atau tidak puas.

\section{Sikap Konsumen}

Sikap merupakan ungkapan perasaan konsumen tentang suatu objek apakah disukai atau tidak. Sikap juga menggambarkan kepercayaan konsumen terhadap berbagai atribut dan manfaat objek tersebut. Menurut Rasmikayati dkk (2017) sikap merupakan predisposisi (keadaan mudah terpengaruh) yang dipelajari untuk menanggapi secara konsisten terhadap suatu objek, baik dalam bentuk tanggapan positif maupun tanggapan negatif. Konsep sikap sangat berkaitan dengan konsep kepercayaan (belief) dan perilaku (behavior). Teori-teori sikap mengemukakan bahwa sikap konsumen terhadap suatu produk akan mempengaruhi perilaku atau tindakan konsumen terhadap produk tersebut.

\section{METODE PENELITIAN}

\section{Metode Pengambilan Sampel dan Data}

Populasi pada penelitian ini adalah seluruh konsumen di Kota Pekanbaru yang menggunakan produk minyak goreng curah dan minyak goreng kemasan. Teknik pengambilan sampel untuk survei dengan menggunakan mall-intercept, dimana peneliti mendekati konsumen potensial yang sedang berada di pusat perbelanjaan. Jika konsumen bersedia untuk berpartisipasi maka dilanjutkan dengan wawancara. Jumlah sampel ditetapkan dengan menggunakan rumus Slovin (Umar, 2003), dengan rumus sebagai berikut:

$$
\mathrm{n}=\frac{\mathrm{N}}{\mathrm{Ne}^{2}+1}
$$

Dimana:

$$
\begin{array}{ll}
\mathrm{n} & =\text { Ukuran sampel } \\
\mathrm{N} & =\text { Ukuran populasi } \\
\mathrm{e} & =\text { Tingkat kesalahan }
\end{array}
$$

Populasi pada penelitian ini adalah jumlah penduduk di Kota Pekanbaru yaitu 1.091.088 jiwa pada tahun 2017. Berdasarkan perhitungan dengan rumus Slovin diperoleh hasil 99,99 sehingga penulis menetapkan untuk mengambil sampel sebanyak 100 orang.

\section{Analisis Data}

Model Sikap

Sikap konsumen terhadap pembelian minyak goreng curah atau kemasan di Kota Pekanbaru dianalisis dengan model Fishbein dengan rumus sebagai berikut

$$
A B=\sum_{\mathrm{i}=1}^{n} b_{\mathrm{i}} \mathrm{e}_{\mathrm{i}}
$$

(Umar, 2000)

Nilai bi dan ei masing-masing diperoleh dengan menggunakan rumus sebagai berikut :

$$
b i=\frac{\sum_{i=1}^{n} r_{i} f\left(x_{i}\right)}{n} \quad \text { dan } \quad \text { ei }=\frac{\sum_{i=1}^{n} r_{i} f\left(y_{i}\right)}{n}
$$

Keterangan :

ri $=$ Bobot skor ke-i

$\mathrm{f}(\mathrm{xi})=$ Jumlah responden yang memiliki bobot skor ke-i untuk variabel keyakinan (bi)

$\mathrm{f}(\mathrm{yi})=$ Jumlah responden yang memiliki bobot skor ke-i untuk variabel evaluasi (ei)

$\mathrm{AB}=$ Sikap total individu terhadap atribut minyak goreng curah atau kemasan

bi = Kekuatan keyakinan konsumen terhadap atribut minyak goreng curah atau kemasan

ei $=$ Evaluasi terhadap atribut minyak goreng curah atau kemasan

$\mathrm{n}=$ Jumlah kriteria atribut minyak goreng curah atau kemasan yang relevan

Bobot $=\mathrm{a}: 3, \mathrm{~b}: 2, \mathrm{c}: 1, \mathrm{~d}:-1, \mathrm{e}:-2$, dan $\mathrm{f}$ : $-3$

Azwar (2012) berpendapat struktur sikap terdiri dari tiga komponen yang saling menunjang yaitu:

1. Komponen kognitif (Cognitive component): Komponen kognitif berisi kepercayaan seseorang mengenai apa yang berlaku atau apa yang benar bagi objek sikap.

2. Komponen afektif (Affective component): Komponen afektif menyangkut masalah emosional subjektif seseorang terhadap suatu objek sikap.

3. Komponen perilaku/konatif (Behavioral component): Komponen perilaku atau konatif dalam struktur sikap menunjukkan bagaimana perilaku atau 
kecenderungan berperilaku yang ada dalam diri seseorang berkaitan dengan objek sikap yang dihadapinya.

Sikap yang dimiliki seseorang adalah suatu jalinan atau suatu kesatuan dari berbagai komponen yang bersifat evaluasi. Langkah pertama adalah keyakinan, pengetahuan, dan pengamatan. Kedua, perasaan atau feeling. Ketiga, kecenderungan individu untuk melakukan atau bertindak. Ketiga komponen tersebut saling berkaitan erat. Ketiganya merupakan suatu sistem yang menetap pada diri individu yang dapat menjelmakan penilaian positif atau negatif. Penilaian tersebut disertai dengan perasaan tertentu yang mengarah pada kecenderungan yang setuju (pro) dan tidak setuju (kontra).

Variabel sikap bersifat internal individu, berkaitan langsung dengan objek penelitian dan atribut-atribut langsung yang memiliki peranan penting dalam pengukuran perilaku, karena akan menentukan tindakan apa yang akan dilakukan tanpa dipengaruhi faktor eksternal. Variabel sikap menurut Fishbein terbagi menjadi dua yaitu variabel keyakinan dan variabel evaluasi (Umar, 2000). Dalam penelitian ini komponen atribut minyak goreng untuk analisis variabel keyakinan dan sikap adalah:

1. Atribut yang melekat pada minyak goreng curah dan kemasan

2. Variabel keyakinan

3. Variabel evaluasi

Penentuan nilai sikap berdasarkan skala sikap konsumen dimana keyakinan ideal yang digunakan adalah -3, -2, -1, 0, 1, 2, 3 sehingga diperoleh rentang skala sikap konsumen terhadap minyak goreng curah dan kemasan pada Tabel 1.

Tabel 1.

Rentang Skala Sikap Konsumen

\begin{tabular}{lcc}
\hline $\begin{array}{c}\text { Sikap } \\
\text { konsumen }\end{array}$ & Skor & $\begin{array}{c}\text { Rentang } \\
\text { nilai }\end{array}$ \\
\hline $\begin{array}{l}\text { Sangat Tidak } \\
\text { Baik }\end{array}$ & -3 & $\begin{array}{c}-54,00 \leq \mathrm{AB} \\
<-36,00\end{array}$ \\
\hline Tidak Baik & -2 & $\begin{array}{c}-36,00 \leq \mathrm{AB} \\
<-18,00\end{array}$ \\
\hline $\begin{array}{l}\text { Cukup Tidak } \\
\text { Baik }\end{array}$ & -1 & $\begin{array}{c}-18,00 \leq \mathrm{AB} \\
<0\end{array}$ \\
\hline Netral & 0 & $\mathrm{AB}=0$ \\
\hline Cukup Baik & 1 & $\begin{array}{l}0<\mathrm{AB} \leq \\
18,00\end{array}$ \\
\hline
\end{tabular}

\begin{tabular}{lcc}
$\begin{array}{c}\text { Sikap } \\
\text { konsumen }\end{array}$ & Skor & $\begin{array}{c}\text { Rentang } \\
\text { nilai }\end{array}$ \\
\hline Baik & 2 & $\begin{array}{c}18,00<\mathrm{AB} \\
\leq 36,00\end{array}$ \\
\hline Sangat Baik & 3 & $\begin{array}{c}36,00<\mathrm{AB} \\
\leq 54,00\end{array}$ \\
\hline
\end{tabular}

Keterangan: $\mathrm{AB}=$ Sikap konsumen

\section{Model Norma Subjektif}

Pengaruh norma subjektif yang timbul dari referen yang berdampak terhadap perilaku konsumen dalam pembelian minyak goreng curah dan kemasan di Kota Pekanbaru dianalisis dengan model Fishbein dengan rumus sebagai berikut:

$$
\mathrm{SN}=\sum_{\substack{\mathrm{j}=1 \\(\text { Umar, 2000) }}}^{\mathrm{n}} \mathrm{NB}_{\mathrm{j}} \mathrm{MC}_{\mathrm{j}}
$$

Nilai NBj dan MCj masing-masing diperoleh dengan menggunakan rumus sebagai berikut:

$$
\mathrm{NBj}=\frac{\sum_{\mathrm{j}=1}^{n} \mathrm{r}_{\mathrm{i}} \mathrm{f}\left(\mathrm{x}_{\mathrm{j}}\right)}{\mathrm{n}} \text { dan } \mathrm{MCj}=\frac{\sum_{\mathrm{j}=1}^{\mathrm{n}} \mathrm{r}_{\mathrm{i}} \mathrm{f}\left(\mathrm{y}_{\mathrm{j}}\right)}{\mathrm{n}}
$$

Keterangan :

$\mathrm{rj}=$ Bobot skor ke-j

$\mathrm{f}(\mathrm{xi})=$ Jumlah responden yang memiliki bobot skor ke-i untuk variabel keyakinan normatif $(\mathrm{NBj})$

$\mathrm{f}(\mathrm{yi})=$ Jumlah responden yang memiliki bobot skor ke-i untuk variabel motivasi (MCj)

$\mathrm{SN}=$ Norma subjektif

$\mathrm{NBj}=$ Keyakinan normatif individu

$\mathrm{MCj}=$ Motivasi dari referen

$\mathrm{n} \quad=$ Jumlah referen yang relevan

Bobot $=\mathrm{a}: 3, \mathrm{~b}: 2, \mathrm{c}: 1, \mathrm{~d}:-1, \mathrm{e}:-2$, dan $\mathrm{f}$ $:-3$

Variabel ini bersifat eksternal dan mempunyai pengaruh terhadap perilaku individu. Variabel ini menekankan bahwa referen atau masyarakat di sekitar dan kebijakan pemerintah tentang minyak goreng wajib kemasan yang dipercaya berpengaruh terhadap keputusan konsumen dalam membeli minyak goreng.

Variabel norma subjektif menurut Fishbein terbagi menjadi dua:

1. Variabel keyakinan normatif, yaitu keyakinan normatif konsumen bahwa 
masyarakat sekitar dan kebijakan pemerintah (referen) yang berpendapat bahwa konsumen sebaiknya membeli minyak goreng.

2. Variabel motivasi, yaitu motivasi konsumen untuk menuruti pendapat masyarakat sekitar dan kebijakan pemerintah (referen) untuk membeli minyak goreng.

3. Komponen-komponen dari variabel keyakinan normatif dan variabel motivasi terdiri dari: masyarakat sekitar dan kebijakan pemerintah tentang minyak goreng wajib kemasan.

\section{Analisis Perilaku}

Analisis perilaku digunakan untuk mengetahui bagaimana perilaku konsumen terhadap pembelian minyak goreng curah dan kemasan yang dianalisis menggunakan Theory of Reasoned Action (TRA). Langkah pengukuran ini dilakukan seperti dalam mengukur sikap konsumen. Teori tindakan yang beralaskan gambaran pengintegrasian komponenkomponen sikap secara menyeluruh ke dalam struktur yang dimaksudkan untuk menghasilkan penjelasan yang lebih baik maupun peramalan yang lebih baik mengenai perilaku. Model TRA digambarkan dengan formula:

$\mathrm{B} \sim \mathrm{BI}=\mathrm{W}_{1}(\mathrm{AB})+\mathrm{W}_{2}(\mathrm{SN})$

Keterangan :

$\mathrm{BI}=$ Perilaku konsumen (behaviour intention)

$\mathrm{AB}=$ Sikap total individu terhadap atribut minyak goreng curah atau kemasan

$\mathrm{SN}=$ Norma subjektif

$\mathrm{W}_{1} \mathrm{~W}_{2}=$ Nilai $\mathrm{W}_{1}$ dan $\mathrm{W}_{2}$ didapat dengan menggunakan pendekatan dari data empiris yaitu dengan menghitung skor jawaban responden terhadap norma subjektif. Nilai $\mathrm{W}_{1}$ didapat dari persentase skor pilihan jawaban negatif (-), nilai $\mathrm{W}_{2}$ didapat dari persentase skor pilihan jawaban positif (+). Nilai $\mathrm{W}_{1}+\mathrm{W}_{2}=100 \%$. Dapat dikatakan jika pengambilan keputusan lebih banyak dilakukan oleh konsumen sendiri, maka nilai $\mathrm{W}_{1}>\mathrm{W}_{2}$. Sebaliknya, jika pengambilan keputusan lebih banyak dilakukan kerena pengaruh pihak lain, maka $\mathrm{W}_{1}<\mathrm{W}_{2}$.

\section{PEMBAHASAN}

Analisis Sikap Konsumen terhadap Pembelian Minyak Goreng Curah dan Kemasan di Kota Pekanbaru

Sikap merupakan bentuk evaluasi, perasaan, dan kecenderungan konsumen yang konsisten terhadap suka atau tidak suka atas sebuah objek atau ide (Kotler dan Amstrong 2007). Sikap dapat memengaruhi keputusan pembelian oleh konsumen (Wahyuni, 2008) karena sikap merupakan bentuk dari psikologis konsumen. Menurut Tarmizi (2017), sikap konsumen merupakan faktor penting yang memengaruhi keputusan konsumen. Menurut Manossoh dkk (2015), keputusan pembelian adalah tindakan yang dilakukan konsumen untuk melakukan pembelian sebuah produk. Maka pengambilan keputusan pembelian konsumen merupakan suatu proses pemilihan salah satu dari beberapa alternatif penyelesaian masalah dengan tindak lanjut yang nyata. Setelah itu konsumen dapat melakukan evaluasi pilihan dan kemudian dapat menentukan sikap yang akan diambil selanjutnya.

Sikap konsumen terhadap minyak goreng curah dan kemasan akan menentukan kemungkinan konsumen membeli atau tidak produk tersebut, semakin baik sikap konsumen terhadap produk minyak goreng kemasan atau curah maka semakin tinggi kemungkinan konsumen tersebut membeli produk tersebut. Sikap konsumen terhadap minyak goreng di Kota Pekanbaru dibedakan menjadi dua berdasarkan jenis minyak goreng yang dijual yaitu minyak goreng curah dan minyak goreng kemasan. Sikap konsumen terhadap minyak goreng curah dan kemasan ditentukan oleh sikap konsumen terhadap atribut yang melekat. Pada penelitian ini, model atribut Fishbein digunakan untuk mengukur $\mathrm{AB}$ yaitu sikap seseorang terhadap minyak goreng curah dan kemasan melalui atribut yang melekat pada minyak goreng curah dan kemasan.

Sikap yang ada pada konsumen akan dipengaruhi oleh keyakinan (bi) dan evaluasi (ei) terhadap atribut yang ada pada minyak goreng curah dan kemasan. Keyakinan konsumen (bi) dalam membeli minyak goreng 
curah maupun kemasan di Kota Pekanbaru merupakan bentuk reaksi konsumen terhadap minyak goreng yang akan dibeli. Keyakinan juga dapat diartikan sebagai bentuk dari tingkat kepercayaan konsumen terhadap atribut yang melekat pada minyak goreng yang akan dibeli, artibut berfungsi sebagai landasan bagi konsumen dalam membeli minyak goreng baik curah atau kemasan di Kota Pekanbaru. Evaluasi (ei) adalah analisis pernyataan tentang penilaian yang timbul dari dalam diri konsumen akibat membeli produk minyak goreng curah dan kemasan tanpa dipengaruhi faktor-faktor dari luar/eksternal seperti tingkat pendapatan, budaya dan orangorang sekitar. Menurut Gitosudarmo (2007), atribut produk adalah suatu komponen yang merupakan sifat-sifat produk yang menjamin agar produk tersebut dapat memenuhi kebutuhan dan keinginan yang diharapkan oleh pembeli. Atribut produk dapat berupa sesuatu yang berwujud (tangible) maupun sesuatu yang tidak berujud (intangible). Atribut yang berwujud dapat berupa merek, kualitas produk, desain produk, label produk, kemasan dan sebagainya. Sedangkan yang tidak berwujud seperti kesan atau image konsumen terhadap nama merek. Setiap produk akan memiliki atribut yang berbeda dengan produk lain (Randang, 2013).

\section{Sikap Konsumen terhadap Produk Minyak Goreng Curah}

Sikap konsumen terhadap produk minyak goreng curah ditentukan oleh atribut minyak goreng curah. Atribut minyak goreng curah adalah harga yang murah, warna yang jernih, higienis, nilai gizi baik, ukurannya bervariasi dan kemasan yang praktis (Tabel 2).

Tabel 2.

Sikap Konsumen terhadap Produk Minyak Goreng Curah (AB)

\begin{tabular}{lllll}
\hline No & $\begin{array}{c}\text { Atribut } \\
\text { minyak } \\
\text { goreng } \\
\text { curah }\end{array}$ & bi & ei & $\begin{array}{c}\text { AB } \\
\text { (bi } \mathbf{x} \\
\text { ei) }\end{array}$ \\
\hline 1 & $\begin{array}{l}\text { Harga } \\
\text { yang } \\
\text { murah }\end{array}$ & 1,77 & 2,54 & 4,49 \\
\hline 2 & Warna \\
& $\begin{array}{llll}\text { yang } \\
\text { jernih }\end{array}$ & 1,77 & 1,15 & 2,04 \\
\hline
\end{tabular}

\begin{tabular}{|c|c|c|c|c|}
\hline No & $\begin{array}{c}\text { Atribut } \\
\text { minyak } \\
\text { goreng } \\
\text { curah }\end{array}$ & bi & ei & $\begin{array}{r}\mathbf{A B} \\
\text { (bi } x \\
\text { ei) }\end{array}$ \\
\hline 3 & Higienis & 1,15 & 0,31 & 0,36 \\
\hline 4 & $\begin{array}{l}\text { Nilai gizi } \\
\text { baik }\end{array}$ & 1,69 & 1,08 & 1,82 \\
\hline 5 & $\begin{array}{l}\text { Ukuran } \\
\text { nya } \\
\text { bervariasi }\end{array}$ & 1,85 & 1,85 & 3,41 \\
\hline 6 & $\begin{array}{l}\text { Kemasan } \\
\text { yang } \\
\text { praktis }\end{array}$ & 1,00 & 0,38 & 0,38 \\
\hline \multicolumn{4}{|c|}{ Nilai Sikap Konsumen } & 12,50 \\
\hline$\overline{\mathrm{Ket}}$ & gan: bi & $\begin{array}{l}=\text { Keyak } \\
=\text { Evalua } \\
=\text { Sikap }\end{array}$ & $\begin{array}{l}n \text { kol } \\
\text { rons } \\
\text { sum }\end{array}$ & men \\
\hline
\end{tabular}

Keyakinan (bi) adalah tingkat kepercayaan konsumen terhadap atribut yang muncul ketika akan membeli minyak goreng. Tabel 2 menunjukkan bahwa atribut utama yang menjadi pertimbangan konsumen ketika akan membeli minyak goreng curah adalah ukuran yang bervariasi dengan nilai persentase bi 1,85 . Konsumen meyakini minyak goreng curah memiliki ukuran yang bervariasi karena dapat dibeli dalam ukuran 250 gram, 500 gram, $1 \mathrm{~kg}$ bahkan bisa disesuaikan dengan kebutuhan sehingga ukuran yang bervariasi sebagai atribut utama yang dipertimbangkan ketika akan membeli minyak goreng curah.

Evaluasi (ei) adalah penilaian konsumen terhadap atribut setelah membeli dan menggunakan minyak goreng. Evaluasi ini muncul dari dalam diri konsumen tanpa dipengaruhi oleh faktor eksternal. Berdasarkan Tabel 2, terdapat perubahan atribut utama yang dipertimbangkan dari sebelum membeli dan setelah membeli minyak goreng curah yaitu harga yang murah dengan nilai ei 2,54. Hal ini menunjukkan bahwa setelah membeli dan menggunakan minyak goreng curah, konsumen menilai harga yang murah menjadi pertimbangan utama. Berdasarkan hasil wawancara konsumen menilai harga yang murah menjadi pertimbangan karena menurut konsumen semakin besar ukuran minyak goreng curah maka akan lebih murah. Minyak goreng curah ukuran 250 gram dengan harga Rp 3.000 sedangkan ukuran $1 \mathrm{~kg} \mathrm{Rp} \mathrm{10.000,} \mathrm{sehingga}$ 
konsumen berpendapat bahwa lebih menguntungkan jika membeli minyak goreng dengan ukuran $1 \mathrm{~kg}$. Amalia dkk (2010) menjelaskan bahwa masih cukup tingginya harga minyak goreng bagi sebagian masyarakat dan kurangnya pengetahuan membuat masyarakat sering kali menggunakan minyak goreng yang telah dipakai hingga berulang kali.

Berdasarkan nilai variabel keyakinan (bi) dan evaluasi (ei) maka konsumen memutuskan sikap dalam membeli produk minyak goreng curah dengan pertimbangan utama yaitu harga yang murah, ukurannya bervariasi dan warna yang jernih dengan nilai sikap masing-masing 4,49, 3,41 dan 2,04. Harga yang murah menjadi atribut utama karena merupakan penilaian utama konsumen akibat membeli minyak goreng curah. Kemudian ukuran yang bervariasi menjadi atribut selanjutnya yang mempengaruhi sikap konsumen karena merupakan keyakinan utama konsumen ketika akan membeli minyak goreng curah.

Atribut warna yang jernih mempengaruhi sikap konsumen karena dalam membeli minyak goreng curah konsumen akan memilih warna yang terlihat jernih kuning muda ataupun keemasan sebagai tolok ukur kebersihan minyak goreng curah tersebut. Menurut penelitian Haryanti dkk (2014) warna kuning keemasan yang banyak dipilih oleh konsumen karena bagi konsumen warna tersebut menunjukkan bahwa minyak goreng tersebut berkualitas dan sehat. Sedangkan warna kuning kemerahan dianggap kurang sehat dan warna kuning ke arah putih dianggap terlalu jernih seperti air.

Tabel 2 juga menunjukkan bahwa sikap konsumen terhadap produk minyak goreng curah bernilai positif dengan total nilai 12,50 . Artinya secara keseluruhan sikap konsumen terhadap minyak goreng curah dinilai baik. Total nilai sikap konsumen yang bernilai 12,50 berdasarkan rentang skala (Tabel 1) termasuk dalam kategori cukup baik $(0<\mathrm{AB}$ $\leq$ 18,00). Secara keseluruhan konsumen mempunyai sikap yang cukup baik terhadap atribut-atribut minyak goreng curah.

\section{Sikap Konsumen terhadap Produk Minyak} Goreng Kemasan

Sikap konsumen terhadap produk minyak goreng kemasan ditentukan oleh atribut minyak goreng kemasan. Atribut minyak goreng kemasan sama dengan minyak goreng curah. Sikap konsumen terhadap produk minyak goreng kemasan di Kota Pekanbaru dapat dilihat pada Tabel 3 .

Tabel 3.

Sikap Konsumen terhadap Produk Minyak Goreng Kemasan (AB)

\begin{tabular}{lllll}
\hline No & $\begin{array}{l}\text { Atribut } \\
\text { minyak } \\
\text { goreng } \\
\text { curah }\end{array}$ & bi & ei & $\begin{array}{c}\text { AB } \\
\text { (bi x } \\
\text { ei) }\end{array}$ \\
\hline 1 & $\begin{array}{l}\text { Harga } \\
\text { yang } \\
\text { murah }\end{array}$ & 0,91 & 1,29 & 1,17 \\
\hline 2 & $\begin{array}{l}\text { Warna } \\
\text { yang } \\
\text { jernih }\end{array}$ & 1,82 & 1,98 & 3,59 \\
\hline 3 & Higienis & 2,37 & 2,49 & 5,91 \\
\hline 4 & $\begin{array}{l}\text { Nilai gizi } \\
\text { baik }\end{array}$ & 2,23 & 2,32 & 5,18 \\
\hline 5 & $\begin{array}{l}\text { Ukuran } \\
\text { nya } \\
\text { bervariasi }\end{array}$ & 2,01 & 1,83 & 3,68 \\
\hline 6 & $\begin{array}{l}\text { Kemasan } \\
\text { yang } \\
\text { praktis }\end{array}$ & 2,16 & 2,09 & 4,52 \\
\hline \multicolumn{4}{l}{ Nilai Sikap Konsumen } \\
\hline
\end{tabular}

Keterangan: bi = Keyakinan konsumen ei $=$ Evaluasi konsumen $\mathrm{AB}=$ Sikap konsumen

Tabel 3 menunjukkan bahwa atribut utama yang menjadi keyakinan (bi) konsumen ketika akan membeli minyak goreng kemasan adalah higienis dengan nilai persentase bi 2,37. Konsumen memiliki keyakinan minyak goreng kemasan higienis karena mengalami 2 kali proses penyaringan dan dikemas langsung dari pabrik sehingga lebih bersih dan mutu terjaga. Evaluasi (ei) konsumen terhadap atribut minyak goreng setelah membeli dan menggunakan adalah tetap dengan keyakinan yaitu atribut higienis dengan nilai ei 2,49. Hal ini menunjukkan bahwa perilaku konsumen setelah membeli sama dengan keyakinan yaitu tetap menilai higienis sebagai atribut utama yang dipertimbangkan dalam membeli minyak goreng kemasan. Menurut pengamatan di lapangan, konsumen memiliki keyakinan minyak goreng kemasan higienis karena sudah memiliki merek. Produk yang sudah 
memiliki merek maka proses produksi mulai dari penyaringan hingga pengemasan lebih steril sesuai Standar Operasional Prosedur (SOP) pabrik, sehingga mutu lebih baik dan terjaga.

Berdasarkan nilai variabel keyakinan (bi) dan evaluasi (ei) maka konsumen memutuskan sikap dalam membeli produk minyak goreng kemasan dengan pertimbangan utama yaitu higienis $(5,91)$, nilai gizi baik $(5,18)$ dan kemasan yang praktis $(4,52)$. Atribut higienis menjadi atribut utama yang mempengaruhi sikap konsumen karena merupakan atribut yang diyakini sebelum membeli dan dinilai konsumen paling menentukan sikap konsumen setelah membeli minyak goreng kemasan. Kemudian nilai gizi baik menjadi atribut yang mempengaruhi sikap konsumen karena minyak goreng kemasan diniai memiliki gizi yang baik berdasarkan komposisi yang tertera lengkap pada keterangan seperti kandungan energi total, lemak total, omega 6 dan omega 3 . Selanjutnya kemasan yang praktis menjadi atribut yang mempengaruhi sikap konsumen karena minyak goreng kemasan dikemas dalam bentuk yang baik yaitu bantal, stand pouch, cup, botol dan jerigen. Bentuk kemasan ini menurut konsumen lebih menjamin minyak goreng tidak mudah tumpah dan lebih kokoh sehingga lebih aman. Total nilai sikap yang terdapat pada Tabel 3 menjelaskan bahwa konsumen memiliki sikap positif terhadap minyak goreng kemasan dibuktikan dengan total nilai sikap konsumen mencapai 24,04, hal tersebut menunjukan bahwa secara keseluruhan sikap konsumen terhadap minyak goreng kemasan baik karena bernilai positif. Total nilai sikap konsumen yang bernilai 24,04 berdasarkan rentang skala (Tabel 1) berada pada kategori baik $(18,00<$ $\mathrm{AB} \leq 36,00)$. Secara keseluruhan konsumen mempunyai sikap yang baik terhadap atributatribut yang terdapat pada minyak goreng kemasan.

\section{Analisis Norma Subjektif Konsumen terhadap Pembelian Minyak Goreng Curah dan Kemasan di Kota Pekanbaru}

Norma subjektif terbentuk karena adanya keyakinan normatif dan motivasi dari referen yang dipercayai konsumen. Adapun referen yang digunakan dalam hal ini yaitu masyarakat sekitar dan kebijakan pemerintah.
Kebijakan pemerintah yang dimaksud adalah kebijakan pemerintah tentang minyak goreng wajib kemasan. Referen bertindak sebagai stimulus (pemberi pengaruh) yang artinya seseorang melakukan tindakan karena adanya orang lain atau kejadian lain yang menjadi acuan.

\section{Norma Subjektif Konsumen terhadap Pembelian Minyak Goreng Curah}

Norma subjektif konsumen terhadap pembelian minyak goreng curah dipengaruhi oleh keyakinan normatif (konsumen dalam membeli minyak goreng curah dipengaruhi oleh masyarakat sekitar dan kebijakan pemerintah) dan juga motivasi (konsumen dalam membeli minyak goreng curah terpengaruh oleh ajakan masyarakat sekitar dan kebijakan pemerintah). Selanjutnya dapat dilihat pada Tabel 4 .

Tabel 4.

Norma Subjektif Konsumen terhadap Produk Minyak Goreng Curah

\begin{tabular}{ccccc}
\hline $\begin{array}{c}\text { N } \\
\text { o }\end{array}$ & Referen & NBj & MCj & $\begin{array}{c}\text { SN } \\
\text { (NBj x } \\
\text { MCj) }\end{array}$ \\
\hline 1 & $\begin{array}{l}\text { Masyara- } \\
\text { kat sekitar }\end{array}$ & $-1,85$ & $-2,00$ & 3,69 \\
\hline 2 & $\begin{array}{l}\text { Kebijakan } \\
\text { pemerin- } \\
\text { tah }\end{array}$ & $-2,92$ & $-2,92$ & 8,54 \\
\hline \multicolumn{3}{c}{ Norma Subjektif Konsumen } & 12,24
\end{tabular}

Keterangan: $\mathrm{NBj}=$ Keyakinan normatif

$\mathrm{MCj}=$ Motivasi

$\mathrm{SN}=$ Norma subjektif

Berdasarkan Tabel 4, norma subjektif konsumen terhadap minyak goreng curah bernilai 12,24. Artinya bahwa secara keseluruhan pengaruh referen masyarakat sekitar dan kebijakan pemerintah menjadi acuan konsumen dalam membeli minyak goreng curah. Padahal sebelumnya referen masyarakat sekitar dan kebijakan pemerintah tidak menjadi acuan konsumen dikarenakan masing-masing variabel bernilai negatif. Sehingga secara sistematis perkalian negatif dengan negatif menghasilkan nilai positif, yang artinya referen masyarakat sekitar dan kebijakan pemerintah yang sebelumnya tidak menjadi acuan setelah dihitung secara sistematis maka referen menjadi acuan 
konsumen dalam membeli minyak goreng curah.

Norma Subjektif Konsumen terhadap Pembelian Minyak Goreng Kemasan

Selain melihat norma subjektif konsumen terhadap pembelian minyak goreng curah, pada penelitian ini juga melihat norma subjektif konsumen terhadap pembelian minyak goreng kemasan yang dapat dilihat pada Tabel 5.

Tabel 5.

Norma Subjektif Konsumen terhadap Produk Minyak Goreng Kemasan

\begin{tabular}{|c|c|c|c|c|}
\hline $\begin{array}{l}\mathbf{N} \\
\mathbf{0}\end{array}$ & Referen & $\mathbf{N B j}$ & $\mathbf{M C j}$ & $\begin{array}{c}\text { SN } \\
(\mathbf{N B j} \mathbf{x} \\
\text { MCj) }\end{array}$ \\
\hline 1 & $\begin{array}{l}\text { Masyarak } \\
\text { at sekitar }\end{array}$ & $-1,10$ & $-1,21$ & 1,33 \\
\hline 2 & $\begin{array}{l}\text { Kebijakan } \\
\text { pemerin } \\
\text { Tah }\end{array}$ & $-1,80$ & $-1,91$ & 3,44 \\
\hline \multicolumn{4}{|c|}{ Norma Subjektif Konsumen } & 4,78 \\
\hline \multicolumn{2}{|c|}{ Keterangan: $\mathrm{N}$} & $\begin{array}{l}=\text { Keyal } \\
=\text { Moti } \\
=\text { Norm }\end{array}$ & an $n$ & \\
\hline
\end{tabular}

Tabel 5 menunjukkan bahwa nilai norma subjektif konsumen terhadap minyak goreng kemasan adalah 4,78. Artinya bahwa secara keseluruhan pengaruh referen masyarakat sekitar dan kebijakan pemerintah menjadi acuan konsumen dalam membeli minyak goreng kemasan. Sama halnya dengan norma subjektif konsumen terhadap minyak goreng curah, norma subjektif konsumen terhadap minyak goreng kemasan ini awalnya bernilai negatif untuk masing-masing referen baik pada keyakinan normatif maupun motivasi konsumen. Namun setelah dihitung sistematis diperoleh nilai yang positif sehingga referen masyarakat sekitar dan kebijakan pemerintah juga menjadi acuan konsumen dalam membeli selain pertimbangan sikap konsumen dari atribut.

Analisis Perilaku Konsumen terhadap Pembelian Minyak Goreng Curah dan Kemasan di Kota Pekanbaru

Perilaku konsumen terhadap pembelian minyak goreng curah dan kemasan di Kota Pekanbaru dibentuk oleh dua komponen yaitu sikap konsumen terhadap produk minyak goreng dan norma subjektif konsumen terhadap pembelian minyak goreng. Perilaku konsumen ini akan melihat komponen mana yang lebih mempengaruhi konsumen dalam membeli minyak goreng curah dan kemasan, apakah pengaruh dari dalam diri konsumen atau pengaruh dari luar.

\section{Perilaku Konsumen terhadap Pembelian} Minyak Goreng Curah

Berdasarkan skor jawaban konsumen terhadap norma subjektif pembelian minyak goreng curah, dapat dihitung bobot empiris menggunakan persentase rata-rata, yang dapat dilihat pada Tabel 6 .

Tabel 6.

Bobot Empiris Sikap $\left(\mathrm{W}_{1}\right)$ dan Norma

Subjektif $\left(\mathrm{W}_{2}\right)$ Konsumen Minyak Goreng Curah

\begin{tabular}{crcr}
\hline $\mathbf{W}_{\mathbf{1}}$ & Persentase & $\mathbf{W}_{\mathbf{2}}$ & Persentase \\
\hline 11 & 84,62 & 2 & 15,38 \\
\hline 13 & 100,00 & 0 & 0,00 \\
\hline 12 & 92,31 & 1 & 7,69 \\
\hline 13 & 100,00 & 0 & 0,00 \\
\hline $\begin{array}{l}\text { Rata- } \\
\text { rata }\end{array}$ & 94,23 & & 5,77 \\
\hline
\end{tabular}

Keterangan: $\mathrm{W}_{1}$ diperoleh dari jumlah skor negatif, $\mathrm{W}_{2}$ diperoleh dari jumlah skor positif

Tabel 6 menunjukkan bahwa $\mathrm{W}_{1}>\mathrm{W}_{2}$ atau $94,23>5,77$. Berarti pembelian konsumen minyak goreng curah lebih banyak dilakukan bukan karena pengaruh referen (masyarakat sekitar dan kebijakan pemerintah), melainkan karena kesadaran yang timbul dari pribadi konsumen itu sendiri.

Agar lebih meyakini, bahwa total $\mathrm{W}_{1}=1$ dan $\mathrm{W}_{2}=1$, perlu ditentukan bobot mana yang lebih berperan dalam pembentukan maksud perilaku. Misalnya bila maksud perilaku murni berperan, maka $\mathrm{W}_{1}=1$ dan $\mathrm{W}_{2}=0$, bisa juga $\mathrm{W}_{1}=0$ dan $\mathrm{W}_{2}=1$, kalau maksud perilaku semata-mata pengaruh orang lain dan sikap sendiri tidak ada.

Persamaan Fishbein yang digunakan untuk memprediksi perilaku konsumen dalam membeli minyak goreng curah di Kota Pekanbaru adalah sebagai berikut :

$$
\begin{array}{ll}
\mathrm{BI} & =\mathrm{W}_{1}(\mathrm{AB})+\mathrm{W}_{2}(\mathrm{SN}) \\
\mathrm{BI} & =94,23(12,50)+5,77(12,24) \\
\mathrm{BI} & =1.178,16+70,60
\end{array}
$$


$\mathrm{BI} \quad=1.248,76$

Nilai BI >0 maka perilaku konsumen terhadap produk adalah baik, sedangkan BI < 0 maka perilaku konsumen terhadap produk adalah tidak baik. Berdasarkan perhitungan diatas, nilai BI > 0 yaitu sebesar 1.248,76 yang berarti perilaku konsumen terhadap minyak goreng curah adalah baik.

\section{Perilaku Konsumen terhadap Pembelian} Minyak Goreng Kemasan

Selanjutnya untuk mengetahui bagaimana perilaku konsumen dalam membeli minyak goreng kemasan di Kota Pekanbaru dapat dihitung bobot empiris menggunakan persentase rata-rata, yang dapat dilihat pada Tabel 7.

Tabel 7.

Bobot Empiris Sikap $\left(\mathrm{W}_{1}\right)$ dan Norma Subjektif $\left(\mathrm{W}_{2}\right)$ Konsumen Minyak Goreng Kemasan

\begin{tabular}{crcr}
\hline $\mathbf{W}_{\mathbf{1}}$ & Persentase & $\mathbf{W}_{\mathbf{2}}$ & Persentase \\
\hline 65 & 74,71 & 22 & 25,29 \\
\hline 76 & 87,36 & 11 & 12,64 \\
\hline 67 & 77,01 & 20 & 22,99 \\
\hline 78 & 89,66 & 9 & 10,34 \\
\hline $\begin{array}{l}\text { Rata- } \\
\text { rata }\end{array}$ & 82,18 & & 17,82 \\
\hline
\end{tabular}

Keterangan: $\mathrm{W}_{1}$ diperoleh dari jumlah skor negatif, $\mathrm{W}_{2}$ diperoleh dari jumlah skor positif

Tabel 7 menunjukkan bahwa $\mathrm{W}_{1}>\mathrm{W}_{2}$ atau $82,18>17,82$. Berarti pembelian konsumen minyak goreng kemasan lebih banyak dilakukan bukan karena pengaruh referen (masyarakat sekitar dan kebijakan pemerintah), melainkan karena kesadaran yang timbul dari pribadi konsumen itu sendiri. Selanjutnya dilakukan perhitungan pada persamaan Fishbein untuk memprediksi perilaku konsumen dalam membeli minyak goreng kemasan di Kota Pekanbaru sebagai berikut :

$$
\begin{array}{ll}
\mathrm{BI} & =\mathrm{W}_{1}(\mathrm{AB})+\mathrm{W}_{2}(\mathrm{SN}) \\
\mathrm{BI} & =82,18(24,04)+17,82(4,78) \\
\mathrm{BI} & =1.975,70+85,07 \\
\mathrm{BI} & =2.060,77
\end{array}
$$

Berdasarkan perhitungan ini diperoleh bahwa nilai BI > 0 yaitu sebesar 2.060,77 yang berarti bahwa perilaku konsumen terhadap minyak goreng kemasan adalah baik. Berarti dapat disimpulkan bahwa perilaku konsumen dalam membeli minyak goreng kemasan lebih baik daripada minyak goreng curah.

\section{PENUTUP}

Berdasarkan hasil penelitian sikap dan prilaku konsumen minyak goreng dapat diambil kesimpulan bahwa berdasarkan model sikap Fishbein, sikap konsumen bernilai positif terhadap produk minyak goreng curah dan kemasan. Secara keseluruhan konsumen mempunyai sikap yang cukup baik terhadap atribut minyak goreng curah dan atribut minyak goreng kemasan. Atribut utama yang menentukan sikap konsumen terhadap minyak goreng curah adalah harga yang murah, sedangkan atribut utama yang mempengaruhi pada produk minyak goreng kemasan adalah higienis. Berdasarkan Theory of Reasoned Action (TRA), perilaku konsumen terhadap pembelian minyak goreng kemasan lebih baik dibandingkan minyak goreng curah. Maka disarankan produsen dan pelaku usaha minyak goreng curah dan kemasan di Kota Pekanbaru mempertahankan dan meningkatkan atributatribut yang diyakini konsumen sesuai dengan harapan konsumen.

\section{REFERENSI}

Amalia, F., Retnaningsih, dan Irni, R. J. 2010. Perilaku Penggunaan Minyak Goreng Serta Pengaruhnya terhadap Keikutsertaan Program Pengumpulan Minyak Jelantah di Kota Bogor. Jur. Ilm. Kel. \& Kons. Vol. 3 No. 2: 184189.

Aminah, S. 2010. Bilangan Peroksida Minyak Goreng Curah dan Sifat Organoleptik Tempe pada Pengulangan Penggorengan. Jurnal Pangan dan Gizi Vol. 01: 7-13.

Azwar. S. 2012. Penyusunan Skala Psikologis. Pustaka Pelajar Offset. Yogyakarta.

Bukhori, M dan Tutik, E. 2017. Faktor-faktor yang Dipertimbankan dalam Keputusan Pembelian Minyak Goreng Bimoli pada Ibu Rumah Tangga Desa Kebonagung Kecamatan Purworejo Kota Pasuruan. JIBEKA Vol. 11 No. 2: 11-20.

Departemen Perdagangan Republik Indonesia. 2009. Siaran Pers: Pemerintah Luncurkan Secara Resmi "Minyakita" di Yogyakarta dan Surakarta. 
Kementrian Perdagangan. www.kemendag.go.id. Diakses tanggal 15 Januari 2019.

Fitriana. 2015. Analisis Perbandingan Sikap Konsumen dalam Memilih Produk Minyak Goreng Kemasan dan Curah (Studi Kasus Ibu Rumah Tangga di Kota Pekanbaru). JOM FEKON Vol. 2 No. 1: 1-14.

Gitosudarmo. 2007. Manajemen Pemasaran. BPFE. Yogyakarta.

Haryanti, R., Ferry, F. K., Karina, B. L., dan Yulius, Y. R. 2014. Analisis Preferensi Konsumen terhadap Warna Minyak Goreng di Salatiga. $3^{\text {rd }}$ Economics \& Business Research Festival. hal: 257266.

Badan Standardisasi Nasional. 2013. Minyak goreng SNI 3741:2013. http://lib.kemenperin.go.id/neo/detail.p hp? id $=231088$

Kotler, P. dan Amstrong, G. 2007. Prinsipprinsip Pemasaran Edisi 12. Erlangga. Jakarta.

Kotler, P. dan Keller, K.L. 2010. Manajemen Pemasaran. Erlangga. Jakarta.

Lempang, I. R., Fatimawali, dan Nancy, C. P. 2016. Uji Kualitas Minyak Goreng Curah dan Minyak Goreng Kemasan di Manado. PHARMACON Jurnal Ilmiah Farmasi Vol. 5 No. 4: 155-161.

Manossoh, A., Lisbeth M., dan Agus, S.S. 2015. Analisis Perbandingan Sikap Konsumen terhadap Penggunaan Produk Shampoo Clear dan Shampoo Pantene di Winangun. Jurnal EMBA Vol. 3 No. 3: 74-80.

Qorima, R. S., Fembriarti, E.P., dan Adawiyah, R. 2014. Tingkat Kepuasan dan Loyalitas Ibu Rumah Tangga dalam Mengonsumsi Minyak Goreng Kemasan di Kota Bandar Lampung. JIIA Vol. 2 No. 3: 285-294.

Randang, W. 2013. Kualitas Produk, Atribut Produk dan Ekuitas Merek Pengaruhnya terhadap Keputusan Pembelian Minyak Goreng. Jurnal EMBA Vol. 1 No. 13: 701-709.

Rasmikayati, E., Pandi P., Hepi, H., Risyad, M.I., dan Bobby R.S. 2017. Kajian Sikap dan Perilaku Konsumen Dalam Pembelian Kopi Serta Pendapatnya Terhadap Varian Produk dan Potensi
Kedainya. Mimbar Agribisnis. Jurnal Pemikiran Masyarakat Ilmiah Berwawasan Agribisnis Vol. 3 No. 2: 117-133.

Sangadji, E.M. dan Sopiah. 2013. Perilaku Konsumen-Pendekatan Praktis Disertai Himpunan Jurnal Penelitian. Penerbit Andi. Yogyakarta.

Tarmizi, A. 2017. Analisis Sikap Konsumen terhadap Keputusan Pembelian Produk Sepeda Motor Honda Merk Vario pada PD. Daya Motor Sungai Bahar Muaro Jambi. Journal of Economics and Business Vol. 1 No. 1: 18-31.

Tjiptono, F. dan Diana, A. 2016. Pemasaran, Efisiensi \& Aplikasi. Penerbit ANDI. Yogyakarta.

Umar, H. 2000. Riset Pemasaran dan Perilaku Konsumen. PT Gramedia Pustaka Utama. Jakarta.

Umar, H. 2003. Metodologi Penelitian untuk Skripsi dan Tesis Bisnis. PT Gramedia Pustaka. Jakarta.

Wahyuni, D. 2008. Pengaruh Produk, Harga,

Promosi dan Layanan terhadap Keputusan Konsumen membeli Sepeda Motor Kawasaki. Jurnal Ilmu dan Riset Manajemen Vol. 1 No. 1: 25-46.

Weldy. 2010. Pengetahuan Pedagang Gorengan dan Pengelola Warung Makan Tenda tentang Minyak Jelantah. Karya Tulis Ilmiah Universitas Muhammadiyah Palangkaraya.

\section{BIODATA PENULIS}

Yeni Kusumawaty, adalah dosen Jurusan Agribisnis, Fakultas Pertanian, Universitas Riau dan telah menyelesaikan S3 di Curtin University, Australia. Ketertarikan penelitian pada bidang pemasaran, pangan dan agribisnis dan perilaku konsumen.

Susy Edwina, adalah dosen Jurusan Agribisnis, Fakultas Pertanian, Universitas Riau. Ketertarikan penelitian pada bidang kelembagaan pertanian.

Nurny Sofwah Sifqiani, adalah mahasiswa Jurusan Agribisnis, Fakultas Pertanian, Universitas Riau. Ketertarikan penelitian terhadap bidang pemasaran. 